\title{
Minimum Services Standard Model For Infrastructure, Facilities and Utilities of Simple Rental Flats in Surabaya City
}

\author{
$1^{\text {st }}$ Bambang Irawan ${ }^{1}$ \\ \{bbgirw7980@gmail.com ${ }^{1}$ \} \\ Department of Public Administration, Administrative Science Faculty, Institute of Social Sciences \\ and Management STIAMI
}

\begin{abstract}
The purpose of this study was to identify the standard forms of minimum services for Infrastructure, Facilities and Utilities of Simple Rental Flats, and to find a minimum services standart model for Infrastructure, Facilities and Utilities for Simple Rental Flats in Surabaya City. This research was conducted using a qualitative approach, using normative juridical and sociological normative methods. Primary data were analyzed from direct data sources through interviews, especially those relating to behavioral aspects, perceptions and attitudes in understanding the provisions are simple and the extent to which the provisions can fulfill the needs of residents of simple rental flats, and also some secondary data. The study results show that the forms of services for The Facilities of Simple Flats Houses consist of health, worship, shopping, open fields and shared spaces inside. For The Utilities for Simple Rental Flats is the Electricity Network that include the Indonesian National Standard (SNI), environmental health and safety standards. The service model of the Minimum Service Standard for Infrastructure, Facilities and Utilities of Simple Rental Flats is determined by several factors (low income groups, infrastructure, facilities and utilities for simple rental flats, the opportunity to carry out social and religious activities).
\end{abstract}

Keywords: Minimum Services Standart, Infrastructure, Facilities and Utilities, Simple Rental Flats.

\section{Introduction}

The effort in providing decent and affordable housing, especially for Low-Income Communities (MBR) in urban areas that have not been able to fulfill their needs in living places, is by providing simple rental flats. The construction of flat towers that are close to workplaces besides being able to improve the quality of life is also expected to increase the productivity of residents because it can be more efficient in time, reduce congestion and fuel consumption.

On the other hand, since 2012, the Ministry of Public Housing has encouraged for design changes in the construction of simple rental flats, mainly from the number of floors built in one building. The previous design, simple rental flats was built with 4 to 5 floors in one building and was equivalent to a number of units of around 96 units. This design then changes to only 2 to 3 floors in one tower due to the evaluation of the previous construction on floors 4 and 5 not all units are occupied. This change certainly results in a reduction in the number of 
units between 45 to 71 units. This is far from the figures detected by the government, considering that from 2010 to 2014, the total number of simple rental flats that have been built is 843 tower blocks with 18,216 units with a capacity of 143,072 people (Ministry of Public Works, 2015).

To realize a flat that is capable of responding to housing needs, a standard for service is needed which is formulated in the Minimum Service Standards related to Infrastructure, Facilities and Utilities of Flats as a complete physical basis for the environment that enables a residential environment, supporting facilities that function and develop life and supporting facilities for environmental services. However, until now no reference standard has been found that can be used as a minimum service standard related to Infrastructure, Facilities and Utilities of Flats, especially for Simple Rental Flats.

The implementation of public services is closely related to the authority or function carried out by the Regional Government. Regional capacity in identifying regional authority will greatly influence the ability of Regional Governments to develop Minimum Service Standards in accordance with existing areas of government authority. As a reference in minimal fulfillment (Haryati, 2014), Infrastructure, Facilities, and Utilities are one of the components of the Minimum Service Standard stipulated in Law Number 25 of 2009 concerning Public Services. Article 21 describes the Service Standard Components, one of its are Infrastructure, Facilities, and Utilities.

In Law Number 23 of 2014 concerning Local Governments it has classified Government Affairs into two types, namely absolute government affairs, concurrent government affairs, and general government affairs. Public Housing Affairs and Settlement Area is one of several concurrent government affairs which are under the authority of the Local Government in the case of other Mandatory Government Affairs include Education; Health; Public Works and Spatial Planning; Peace of Public Order, and Community Protection; and Social. For this reason, the central government must make a minimum service standards as references for the local government (Khairi, 2015). The purposes of this study are to identify the forms of minimum service standards for Infrastructure, Facilities and Utilities of Simple Rental Flats, and to find a minimum service standards model for Infrastructure, Facilities and Utilities of Simple Rental Flats in the Surabaya City.

As an important instrument in life, housing must have a strong conceptual foundation and cover various dimensions in economic, environmental and social, including ownership, affordability, facilities in residential areas such as public transport (Tufaila, Magribi, and Muljabar, 2014). Infrastructure, Facilities and Utilities are references for prospective residents to choose the type of housing to be occupied. The main factors related to the satisfaction of residents include public infrastructure such as roads, drainage systems, and basic utilities that exist in residential areas (Widiastomo and Yuliastuti, 2013).

Rapoport (1969) stated that a house is an energy created for various complex purposes, and the area used to build a house is a cultural phenomenon, so the shape of the house and its settings are strongly influenced by the culture of the environment in which the building is located. This concept explains that the shape of the house is a picture or symbol of the culture that is owned by a group of people who inhabit the building, in the form of the number of families, social classes and association with neighbors. Roske (1983) explained that the concept of home is a means to realize family members' togetherness, as a personal identity for other families, as a place of refuge from the outside world, where life takes place and as a place where residents can express themselves in carrying out all activities.

Flats are a form of vertical housing development considered to be one of the best alternatives for now, this is due to increasing land values in urban areas, rapid population 
growth, and scarcity of housing in cities (Nurdiani, 2009). Rental flats are also expected to function as one of the best stimuli in solving slum regional development problems in urban areas, in addition to being part of the urban renewal itself (Hardiman, 2009). The main reason for the construction of flats is the efficiency of land use to produce a more regular and better residential pattern (Rika, 2009).

There are several results of previous studies related to the evaluation of Minimum Service Standards for Infrastructure, Facilities and Utilities. The results of Adimasistra and Pigawati (2016) research explain that the availability of facilities and infrastructure have not fully fulfilled the provisions stipulated in the Indonesian National Standard (SNI). Of the 37 types of facilities and infrastructure based on SNI, only 23 types of facilities and infrastructure were available and $69 \%$ of them did not meet the standards. Of the 23 types of facilities and infrastructure $70 \%$ of the conditions can be said to be good but based on user perceptions, as many as $92 \%$ of users stated that the condition was good. This is influenced by the characteristics of users who have high mobility because they work and not a few users who have low educational characteristics and are over 60 years old. The characteristics of users with these criteria do not understand the function and cannot use the available facilities and infrastructure properly. Research conducted by Khairi (2015) explained that based on data collected by the Directorate General of Regional Autonomy of the Ministry of Home Affairs in 2013, the criteria for achieving environmental health and safety related to Infrastructure, Facilities and Utilities were still below the specified target. From the existing Minimum Service Standards, only $60.18 \%$ of the $100 \%$ target is in accordance with environmental health and safety that supports Infrastructure and Housing Utilities.

\section{Methods}

This research was conducted using a qualitative approach. Moleong (2005) explain that qualitative research is research that uses natural settings, with the intention of interpreting phenomena that occur and are carried out by involving various existing methods. This study also uses the nomative juridical and sociological normative method. Normative juridical research begins with an inventory of positive legal regulations regarding the theme under study. Then, to find out the extent to which the positive law is adequate and meet the needs of the community, sociological normative methods are also carried out by using non-legal data (Zaini, 2011).

The data analyzed in the study includes secondary and primary data. The research uses secondary data as the basic material of research conducted by conducting a search of the regulations and the literature relating to the problems of the minimum service standards of Infrastructure, Facilities and Utilities of simple rental flats that were studied. Data collections for secondary data, carried out with an inventory of regulations and literature relating to the minimum service standards for infrastructure, facilities and utilities of simple rental flats and study them in detail. Primary data collections obtained from direct or first-hand data sources, especially those relating to behavioral aspects, perceptions and attitudes in understanding the provisions of minimum service standards for extent Infrastructure, Facilities and Utilities of simple rental flats and how the provisions can meet the needs of residents simple rental flats. Interviews on primary data were carried out with indeepht interviews to data sources by involving stakeholders such as managers and residents of Simple Flats Rent Grudo and Jambangan as Simple Rental Flats that have the best Infrastructure, Facilities and Utilities in 
the Surabaya City, the Surabaya City Building and Land Management Office and the Housing Expert of the Ministry of Public Works's specially Directorate General of Housing Provision

The study uses qualitative analysis, this is because the data to be collected is mostly qualitative data and produces qualitative data and cannot be categorized statistically. Qualitative analysis used is to review the minimum service standard criteria for Infrastructure, Facilities and Utilities of simple rental flats as the object of research and projected to the reference standards and applicable laws and regulations and then adjusted to the conditions and needs in the field research to generalized as a ideal minimum service standard.

\section{Result and Discussion}

\section{Identifying the Forms of Minimum Service Standards for Infrastructure, Facilities and Utilities of Simple Rental Flats}

There are several rules that become a reference in the provision of Infrastructure, Facilities and Utilities of Flats, including Government Regulation Number 4 of 1998 concerning Flats, Regulation of the Minister of Public Works No. 60 / PRT / 1992 Concerning the Technical Requirements for the Construction of Flats, Minister of Public Works Regulation Number: 05 / Prt / M / 2007 concerning Technical Guidelines for the Construction of High-Level Simple Flats, Regulation of the Minister of Public Housing Number 10 of 2007 concerning Guidelines for Infrastructure Stimulant Assistance, Public Facilities and Utilities for Housing and Settlements, as well as Minister of Public Housing Regulation Number 21 of 2011 concerning Guidelines for Assistance in Flats Aids in classifying references in the provision of Infrastructure, Facilities and Utilities.

In normative juridical terms, some of the standards mentioned above can be described by several standards which must be a reference in the provision for Infrastructure, Facilities and Utilities of Flats. Viewed from a regulatory point of view, there are still differences in setting minimum service standards related to the provision of Infrastructure, Facilities and Utilities of Simple Rental Flats. This is due to the absence of a policy reference in establishing minimum service standards for Infrastructure, Facilities and Utilities for Local Government in building Simple Rental Flats. On the other hand, with the division of authority between the Central Government and Local Governments (Provinces and Municipalities/Cities), it creates ambiguity in carrying out the obligation to provide services. For consideration, the following is a review of five regulations that are used as references in establishing minimum service standards for Infrastructure, Facilities and Utilities of Simple Rental Flats (Table 1).

The results of the review of the regulations are then confirmed by observing the Infrastructure, Facilities and Utilities of Simple Rental Flats to get an overview of the application of regulations in Simple Rental Flats. The results of these observations were continued with interviews with the managers and residents of the Simple Rental Flats in the City of Surabaya, the Surabaya City Building and Land Management Office and the Housing Expert of the Ministry of Public Works specially Directorate of Housing Provision. From the results of the interview obtained criteria that will be analyzed more comprehensively to produce thirteen Minimum Service Standards for Infrastructure, Facilities and Utilities of Simple Rental Flats. Infratructure of Simple Flats Rental includes Environmental Roads, Footpaths, Parking Lots, Drainage), Sanitation, Clean Water and Temporary Landfills. However, the facilities of a Simple Flats for Rent are Health, Religious Services, Shopping, 
Open Fields and Shared Space Inside. Whereas the Utilization of Simple Rental Flats is the Electricity Network.

\section{Minimum Service Standard Service Model for Infrastructure, Facilities and Utilities of Simple Rental Flats}

The conditions of the Simple Rental Flats residents are Low-Income Communities that have not sufficient economic capacity to own their own houses must be taken into consideration in determining rental prices and the location of flats that are easily accessible from the place of work. In addition, the existence of adequate Infrastructure, Facilities and Utilities facilities make Simple Rental Flats the best alternative for these Low Income Communitis with income as a Regional Minimum Wage. This is in line with the concept of Magribi and Muljabar (2014), and Widiastomo and Yuliastuti (2013) which further explain the logical consequences of the level of income of the community with the Infrastructure, Facilities and Utilities available in Simple Rent Flats.

The majority of residents who live in Simple Rent Flats in the Surabaya city are Javanese and most of them are Moslem, so the pattern of social life of the people is still dominantly influenced by Javanese culture and islamic views. The shared space facilities in carrying out routine activities together such as the gathering of the residents' association also colored the life in the Flats. As for the mosque as a place of worship, it is widely used for routine activities such as prayer in congregation, commemorating religious holidays and other religious activities such as tahlilan, kenduri and so on. This empirical analysis is in accordance with the concept put forward by Roske (1983) related to the concept of housing which is a medium that expresses itself in carrying out social activities.

Thirteen types of Infrastructure, Facilities and Utilities available in Simple Rent Flats are Minimum Service Standards that must be available to residents. In observation examined, six of thirteen Minimum Service Standards do not yet have the Indonesian National Standard (SNI). This problem should be a concern of the government as a regulator of the establishment of national standards related to environmental health and safety factors. Research by Adimasistra and Pigawati (2016) and Khairi (2015) that the achievement of the Minimum Service Standards for Infrastructure, Facilities and Utilities is still below 70\%, and still needs to be improved in the future.

From the analysis above, the author tries to design a Minimum Service Standards Model for Infrastructure, Facilities and Utilities of Simple Rental Flats as shown in the following figure:

Figure 1.

Minimum Service Standards Model for Infrastructure, Facilities and Utilities of Simple Rental 


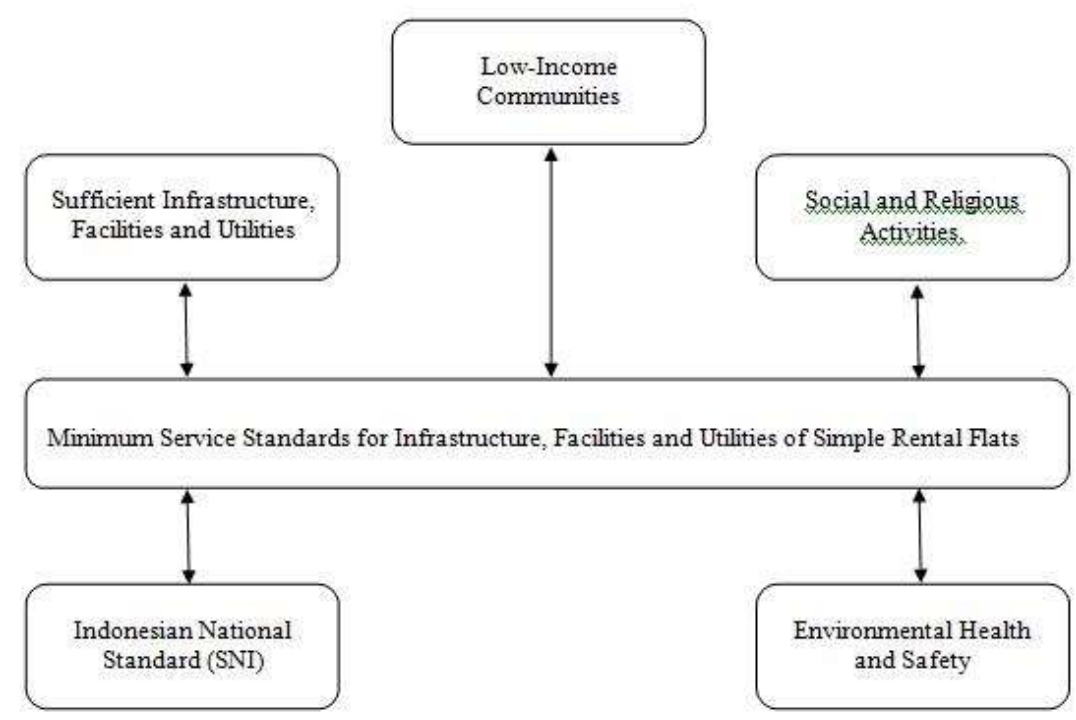

Figure 1. Minimum Service Standards Model for Infrastructure, Facilities and Utilities of Simple Rental Flats

\section{Conclusion}

The analysis carried out to identify the forms of service for the Minimum Service Standards for Infrastructure, Facilities and Utilities for Simple Rent Flats includes Sederhnana Flat Housing Infrastructure covering Environmental Roads, Pathways, Parking Lots, Drainage, Sanitation, Water Clean and Temporary Landfill. Facilities of Simple Flats Houses consist of Health, worship, shopping, open fields and shared spaces inside. The Utilities for Simple Rental Flats is the Electricity Network.

The service model for Minimum Service Standards for Infrastructure, Facilities and Utilities for Simple Flats is determined by a number of factors, including low income communities, sufficient infrastructure, facilities and utilities of simple rental flats, opportunities for social and religious activities, infrastructure, facilities and utilities Simple Rental Flats that have the Indonesian National Standard (SNI), and fulfillment of environmental health and safety standards.

\section{Acknowledgement}

This research was funded by the Institute of Social Sciences and Management STIAMI with the Internal Competition Research Scheme in 2018.

\section{References}

[1]. Adimasistra T., Pigawati B., 2016, Evaluasi Penyediaan Sarana dan Prasarana di Perumahan Puri Dinar Mas Semarang, Jurnal Pengembangan Kota, 4(1): 58-66

[2]. Hardiman, Gagoek, 2009, The Possitive Impact of Walkup Flat Building to Improve the Quality of Slum Area, International Conference and Meeteng on Informal Settlements and Affordable 
Housing (ISAH Network), eds. Happy Santosa, Winny Astuti, Dini W. Astuti, Universitas Sebelas Maret, Surakarta ;

[3]. Kementerian Pekerjaan Umum dan Perumahan Rakyat, 2015, Informasi Statistik Pekerjaan Umum dan Perumahan Rakyat, PUSDATIN

[4]. Haryati, S. 2014, An Analysis of Minimum Service Standards (MSS) in Basic Education: A Case Study at Magelang Municipality, Central Java, Indonesia, International Education Studies; 7(10):32-39

[5]. Khairi H. 2015, The Policy Implementation of Minimum Service Standard in Indonesia: Problems and Challenges, International Journal of Social Sciences, 34 (1): 1-17

[6]. Lexy J. Moleong. 2005. Metodologi Penelitian Kualitatif. Bandung: P.T. Remaja Rosdakarya.

[7]. Nurdiani Nina, 2009, The Influence of Displacement the Success of Sustainable Multy-Storey Housing Development for Low Income Society Housing in Jakarta. International Conference and Meeting on Informal Settlements and Affordable Housing (ISAH Network), eds Happy Santoso, Winny Astuti, Dini W. Astuti, Universitas 11 Maret 2009

[8]. Roske, Mildred Deyo, 1983. Housing in Transition, New York: Holt, Rinehart and Winson

[9]. Tufaila, M., Magribi, L. O., \& Muljabar, D. 2014. Evaluasi Model Penataan Sarana dan Prasarana Lingkungan Permukiman di BTN Graha Asera Desa Lamondowo Kecamatan Andowia Kabupaten Konawe Utara. Kendari.

[10]. Widiastomo, Y., \& Yuliastuti, N. 2013. Kajian Kepuasan Penghuni berdasarkan Kualitas Lingkungan di Perumnas Bukit Sendangmulyo Semarang. Jurnal Teknik PWK, 2(3): 619-627.

\begin{tabular}{|c|c|c|c|c|}
\hline \multicolumn{5}{|c|}{$\begin{array}{l}\text { Tabel 1 } \\
\text { Regulations related Infrastructure, Facilities and Utilities }\end{array}$} \\
\hline $\begin{array}{l}\text { |Government Regulation } \\
\text { I Number } 4 \text { of } 1998\end{array}$ & $\begin{array}{l}\text { Regulation of the Minister } \\
\text { of Public Works No. } 60 / \\
\text { PRT / } 1992\end{array}$ & $\begin{array}{c}\text { Minister of Public } \\
\text { Works Regulation } \\
\text { Number: 05/PRT/M } \\
2007\end{array}$ & $\begin{array}{l}\text { Regulation of the } \\
\text { Minister of Public } \\
\text { Housing Number } 10 \text { of } \\
2007\end{array}$ & $\begin{array}{l}\text { Minister of Public } \\
\text { Housing Regulation } \\
\text { Number } 21 \text { of } 2011\end{array}$ \\
\hline $\begin{array}{l}\text { 1. clean water network } \\
\text { 2. electricity network } \\
\text { 3. gas network } \\
\text { 4. rain water drains } \\
\text { 5. waste water drain } \\
\text { 6. channels and / or landfills } \\
\text { 7. place telephone networks } \\
\text { and communication } \\
\text { devices transportation equipment } \\
\text { 8. trans } \\
\text { 9. fire emergency doors and } \\
\text { stairs; } \\
\text { 10. clothesline; } \\
\text { 11. fire extinguishers; } \\
\text { 12. lightning rod; } \\
\text { 13. alarm device/ system; } \\
\text { 14. smoke-proof doors } \\
\text { certain distances; } \\
\text { 15. electric generator }\end{array}$ & $\begin{array}{l}\text { 1. Building transportation } \\
\text { equipment, } \\
\text { 2. fire emergency doors } \\
\text { and stairs, } \\
\text { 3. tools and fire alamm } \\
\text { systems, } \\
\text { 4. lightning rod, } \\
\text { 5. clean water networks, } \\
\text { 6. rain water drains, } \\
\text { 7. sewerage drains, } \\
\text { 8. garbage collection } \\
\text { place, } \\
\text { 9. clothesline, } \\
\text { 10. completeness } \\
\text { building maintenance, } \\
\text { 11. electricity network, } \\
\text { 12. electric generator, } \\
\text { 13. gas, } \\
\text { 14. a place for possible } \\
\text { telephone network } \\
\text { installation. }\end{array}$ & $\begin{array}{l}\text { 1. road network and } \\
\text { public utilities, } \\
\text { 2. fire extinguishes } \\
\text { network, } \\
\text { 3. trash can, } \\
\text { 4. parking, } \\
\text { 5. drainage channel, } \\
\text { 6. septic tank, } \\
\text { 7. infiltration wells, } \\
\text { 8. guide signs and } \\
\text { gutdoor lighting. }\end{array}$ & $\begin{array}{l}\text { 1. road, } \\
\text { 2. drainage, } \\
\text { 3. clean water, } \\
\text { 4. waste water, } \\
\text { 5. garbage disposal, } \\
\text { 6. electricity network, } \\
\text { 7. public street lighting, } \\
\text { 8. ground reservoir and } \\
\text { drinking water pump } \\
\text { house, and } \\
\text { 9. parking lot. } \\
\text { 10. public stairs } \\
\text { elevators and , or } \\
\text { emergency stairs, } \\
\text { 11. breezeway, } \\
\text { 12. rainwater distribution } \\
\text { system, } \\
\text { 13. sewage and / or dirty } \\
\text { water disposal system } \\
\text { 14. garbage disposal } \\
\text { system, } \\
\text { 15. drinking } \\
\text { system, water } \\
\text { 16. fire extinguishing } \\
\text { system, } \\
\text { 17. lightning rods, and } \\
\text { 18. electricity system. }\end{array}$ & 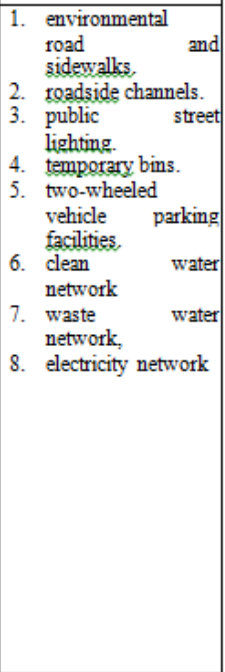 \\
\hline
\end{tabular}

